\title{
En rysk historia
}

\author{
Bengt Jangfeldt \\ Stockholm: Wahlström \& Widstrand 2015 \\ 504 sider. ISBN: 9789146225751
}

Omtalt av Lillian Jorunn Helle [professor, Institutt for fremmedspråk, Universitetet i Bergen, lillian.helle@uib.no]

En rysk historia er ifølge forfatteren en bok av selvbiografisk karakter, men ikke en tradisjonell sådan, siden den rettes inn mot den del av hans liv som omfatter det russiske. Og slik starter vi på en spennende reise - over nesten 500 sider - som begynte da Bengt Jangfeldt, svensk slavist, dosent i slaviske språk, forfatter og oversetter fra russisk, allerede i 12-årsalderen fikk øye på det russiske alfabetet og dets gåtefulle, kyrilliske skrifttegn. Dette ble innledningen til en livsinteresse og en lidenskap, og i boken får vi beretningen om denne fascinasjonen, spekket med skildringer av hans mange møter med russiske kunstnere, forfattere og forskere gjennom en periode på mer enn 50 år. Disse møtene finner sted fra hans første forskningsopphold i Moskva i begynnelsen av 1970-tallet, via bekjentskaper med eksilrussere i USA, Frankrike, Sverige og andre steder, og frem til hans erfaringer i det post-sovjetiske Russland. Gjennom Jangfeldts ofte medrivende fortelling gjenopplever leseren kulturpersonligheter med en nesten mytisk aura som Lili Brik, Vladimir Majakóvskij, Nadézjda og Ósip Mandelsjtám, Víktor Sklovskij, Velimir Khlébnikov, Anna Akhmátova, Borís Pasternák, Román Jakobsón og Aleksándr Solzjenítsyn. Noen av dem har Jangfeldt truffet fysisk. Andre, som futuristen Majakóvskij, kommer han i kontakt med indirekte, gjennom Lili Brik, dikterens muse og vedvarende kjærlighet. Når den svenske stipendiaten lærer denne «grande dame» å kjenne, er hun over 80 år gammel, men frisk av sinn og en gullgruve til informasjon om futuristenes visjoner om en ny politisk og estetisk verden. Hun var også sterkt opptatt av sitt ettermæle, siden de sovjetiske litteraturideologene hadde retusjert henne nesten fullstendig bort fra alle offisielle hagiografier over dikterhøvdingen. Åpenbart så hun den unge slavisten som en mulighet til å rehabilitere sin plass i Majakóvskijs liv, noe som også skjedde blant annet gjennom utgivelsen av brevvekslingen mellom dem, publisert av Jangfeldt i 1982, Kärleken är alltings hjärta.

Foruten avsnittene om Moskva i 1970-årene, får vi høre om Jangfeldts kontakter med kjente eksilrussere, som danseren Mikhaíl Barýsjnikov, dikteren Nina Berberova, forfatteren Andréj Sinjávskij og ikke minst poeten og Nobelpris-vinneren Iósif Bródskij, som Jangfeldt virker å ha hatt et spesielt vennskap med. Det er også interessant å lese om forfatterens arbeid for gjenoppbyggingen - etter kommunismens fall - av den svenske kirken Sankta Katarina og det nye generalkonsulatet og 
kulturhuset (Sverigehuset) i Sankt Petersburg, samt hans innsats for utvikling av temaet Østersjø-forskning, som inkluderer de baltiske landene Polen, Russland, Finland og Tyskland.

Men det er likevel 1970-tallets Moskva som utgiør det innholdsmessige kraftsentrum i En rysk historia. Foruten de legendariske personene vi kommer tett inn på, direkte eller indirekte, formidler forfatteren det nesten magiske skimmeret som hvilte over tilværelsen til de russiske dissidentene i denne epoken. Til tross for den bastante kulturelle og politiske undertrykkelsen og den materielt fattigslige hverdagen, ble kunsten paradoksalt nok holdt hellig, og ethvert kjøkkenrom kunne forvandles til en kultursalong. I all sin ironi kunne de beskjedne leilighetene inneholde kunstverk av umåtelig verdi som en i dag bare ser på museum; som hos Lili Brik, der det rundt om kring på veggene hang bilder av Chagall, Leger, Picasso, Lariónov, Tysjler og Natálja Gontsjaróva.

Det skjær av romantikk som hviler over dissident-Moskva blir imidlertid holdt i sjakk gjennom forfatterens beskrivelse av de intriger og paranoia som sovjet-systemet avfødte: de kunstneriske og intellektuelle kretsene var preget av inngrodd og uforsonlig rivalitet og sjalusi, koblet med en mistenksomhet mot utenforstående og en redsel for KGBs vidtforgrenede nettverk. Som Jangfeldt skriver: en grunn til at han kom så lett $\mathrm{i}$ kontakt med nye mennesker, kunne faktisk være at en besøkende fra utlandet ikke så lett kunne oppfattes som KGB-agent.

Ellers er det bemerkelsesverdig hvilket talent Jangfeldt må ha hatt for å bli kjent med «de riktige folkene», det vil si hvordan han maktet å knytte bånd med den opposisjonelle eliten og fremtredende representanter for russisk-sovjetisk åndsliv. Samtidig minner han om at statusen som utlending gjorde det relativt lett å etablere slike relasjoner, siden mange, særlig i dissidentmiljøene, også så utenlandske forbindelser som en mulighet til å få smuglet forbudt litteratur ut av landet.

Men selv om forfatteren delvis forklarer bakgrunnen for sin tilsynelatende usedvanlige evne til kontaktskapning, kan hans narrativ stundom fremstå som litt vel friksjonsfritt; der forekommer liksom ikke noen alvorlige hindre, verken moralske eller praktiske, på hans russiske reise. Kan dette skyldes, som han selv hevder, at hans minne er selektivt? I alle fall giør denne selektiviteten at hans russiske selvbiografi noen ganger føles vel ufullstendig. Som for eksempel den problematiske affæren med de fire maleriene av suprematisten Kasimir Malévitsj, en ufattelig kunstskatt som eieren, den russiske samleren og kunstviteren Nikolaj Khardizhiev, lot den unge Jangfeldt smugle ut (gjennom diplomatiske kanaler) fra Moskva til Sverige på slutten av 1970-tallet. I etterkant krevde Khardizhiev lerretene tilbake og anklaget Jangfeldt for tyveri, noe Jangfeldt tilbakeviste med at dette var en gave. Da affæren ble allment kjent rundt 2003, ble den blant annet betegnet som en av de største kunstskandaler gjennom tidene på våre nordlige breddegrader, og Jangfeldts renommé var i en periode under hardt press. I boken gir forfatteren rett nok sin version av hendelsene, men så skjematisk og ensidig at leseren sitter tilbake med like mange spørsmål som før, ikke minst i forhold til sakens kompliserte etiske og psykologiske implikasjoner. En mer nyansert fremstilling her kunne bare ha styrket tekstens dybde og gehalt, selv om Jangfeldt selv antyder at psykologiske aspekter ikke er hans sterke side. 
En rysk historia kunne også ha tjent på et klarere fokus på den russiske historien. Selv om avsnittene om for eksempel Axel Munthe og Raoul Wallenberg er opplysende lesning, er deres tilknytning til verkets tittel ganske vage, og de virker i denne sammenheng som avledende sidespor. Boken ville ha vunnet på en enda sterkere konsentrasjon om den eksklusivt russiske delen av forfatterens livsreise, som synes å ha vært fantastisk og mangfoldig nok til ytterligere utdypning. Denne omfattende reisen blir forøvrig gjort ekstra levende gjennom forfatterens private fotografier, som følger beretningen gjennom hele teksten.

Jangfeldts lange og nære forhold til det russiske ender i denne boken i et noe desillusjonert toneleie og i en skuffelse over mangelen på (vestlige) demokratiprosesser i dagens Russland. Forfatterens ikke uventede frustrasjon blir spesielt følbar på bakgrunn av de euforiske visjonene han, $\mathrm{i}$ likhet med mange andre, hadde for nasjonens fremtid etter Sovjetunionens oppløsning. Som en forklaring på den utviklingen vi er vitne til, griper Jangfeldt tilbake til den «klassiske» russiske kampen som utkrystallisertes fra Peter den stores tid, mellom «slavofiler» og «de vestligvendte», for å vise hvordan denne vekslingen fremdeles er virksom. Men i dag veksler den ikke i en vestlig retning, som mange utenfor Russland hadde håpet på, men mot den tradisjonelt russiske polen, og forfatteren ser resignert ingen tegn på en kursendring med det første. Snarere frykter han at landet i dypere strukturell betydning «ikke er reformerbart» og at den russiske veien nå impliserer en samling rundt det han betegner som bysantinske verdier og den ortodoks-konservative ideen om Russland som Det tredje Roma og verdens sentrum. Disse foruroligende forestillingene uttrykker han $\mathrm{i}$ en pregnant formulering: «Frågan är inte om Ryssland kan utan om Ryssland vill avvika från en historisk väg vars första milstolpe restes vid Bysans skinande portar». Dette er et urovekkende spørsmål som på en slående måte markerer avslutningen på Jangfeldts russiske historie - så langt. . . 